Central Sick Asylum for some years. Rather more than 50 years ago he joined Dr. W. B. Page in practice in Carlisle. He was surgeon to the Cumberland Infirmary for half-a-century and a Justice of the Peace for the City of Carlisle.

Dr. Lediard was active till the end of his long life for he was in London in September last. Much sympathy will be felt for his widow and surviving daughter, while many in the North Country will mourn the loss of a distinguished Cumbrian and one of the kindest hearted men who ever lived.

\title{
CORRESPONDENCE
}

\section{THE CAUSATION OF MYOPIA}

To the Editors of The British Journal of Ophthalmology.

SIR, - In the British Journal of Ophthalmology for August, 1932, there appeared an article by Dr. Spencer Walker on the "Causation of Myopia," in which it was suggested that defective calcium metabolism might account for the posterior staphyloma. Whether this be correct or not, there are certain facts to be considered which may be relevant. Long since, careful work, at first in Switzerland, showed that improvements in lighting and school hygiene did not yield all the success anticipated. Subsequently Dr. Maddox made the valuable suggestion that we should endeavour, in effect, to divert myopic people from literary to technical or outdoor occupations and so affect the general condition of the subject. This procedure is valuable but very difficult to apply in practice. In my experience the myopic child wants to read and dislikes technical work.

Dr. Walker's suggestion recalls the work done by Mr. Lang and myself on the refraction of the eyes of mammalia, see Ophthalmic Hospital Reports, Vol. XI, Part 2. We never found, with the possible exception of two monkeys, any wild animal whose eyes were myopic, but we found a number of completely or partly domesticated animals which were myopic. As the only mammals, apart from man, which accommodate to any appreciable extent are monkeys it is clear that close near vision could not account for the myopia in mammals generally, and as monkeys cannot read that factor is excluded.

There is, therefore, every reason to think that some condition of malnutrition is a factor, as we indicated at that time. But it is difficult to understand precisely why the children of myopic parents so often become myopic. Comparative anatomy again furnishes us with an indication of the direction in which an explanation may ultimately be found. 
The following are the results we obtained after a lengthy investigation. Atropine was used for nearly all the smaller animals. Among the animals examined myopia, including mixed astigmatism, was found as follows:-

$\begin{array}{lcccrrrr}\text { Rabbits } \ldots & \ldots & \ldots & 6 & \text { in } & 52 & \text { eyes. } \\ \text { Guinea pigs } & \ldots & \ldots & 5 & , & 26 & , \\ \text { Mice } & \ldots & \ldots & \ldots & \text { None } & ., & 10 & , \\ \text { White rats } & \text { (half } & \text { wild) } & \ldots & 1 & , & 10 & , \\ \text { Cows } & \ldots & \ldots & \ldots & 1 & , & 10 & , \\ \text { Horse } & \ldots & \ldots & \ldots & \text { None } & , & 6 & , \\ \text { Cats } & \ldots & \ldots & \ldots & 4 & , & 14 & , \\ \text { Dogs } & \ldots & \ldots & \ldots & 2 & ., & 6 & ,\end{array}$

The myopia was under $2 \mathrm{D}$. except in guinea pigs where it was much higher in degree. As many of the eyes were emmetropic by retinoscopy there may have been some additional instances of slight myopia.

The following wild animals were examined:-3 deer, 1 jackal, 1 peccary, 1 jeannette cat, 1 paradoxus cat, 1 Australian native cat, 1 mongoose, 2 hyenas, 1 opossum, 1 porcupine. None of these were myopic. Of eleven monkeys two were myopic but we were unable to ascertain how long the monkeys had been in captivity.

From these facts there emerges one definite conclusion, that the prolonged use of eyes for near work is not by any means the chief factor in causation, though it may well be a powerful source of aggravation.

$$
\text { I am, etc., }
$$

JAMES W. BARRETT.

MEEBOURNE,

September, 1932.

\section{NOTES}

Appointment

Hospital.

Midland Ophthalmological Society
THE officers for the current year are as follows:

President: Norman Pike; Vice-President :

B. H. St. Clair Roherts; Treasurer: T. Ash-
Mr. Frank W. LAw has been elected Assistant Surgeon to the Central London Ophthalmic 